\title{
Formation and evolution mechanism of regional haze: a case study in the megacity Beijing, China
}

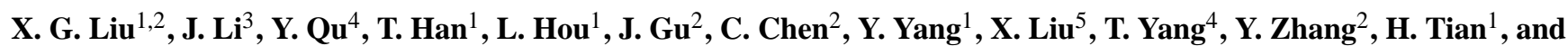 \\ M. $\mathbf{H u}^{2}$ \\ ${ }^{1}$ State Key Laboratory of Water Environment Simulation, School of Environment, Beijing Normal University, \\ Beijing, 100875, China \\ ${ }^{2}$ State Key Joint Laboratory of Environment Simulation and Pollution Control, College of Environmental Sciences and \\ Engineering, Peking University, Beijing, 100871, China \\ ${ }^{3}$ College of Civil Aviation, Nanjing University of Aeronautics and Astronautics, Nanjing, 210016, China \\ ${ }^{4}$ State Key Laboratory of Atmospheric Boundary Layer Physics and Atmospheric Chemistry, Institute of Atmospheric \\ Physics, Chinese Academy of Sciences, Beijing, 100029, China \\ ${ }^{5}$ School of Physics, Peking University, Beijing, 100871, China
}

Correspondence to: X. G. Liu (liuxingang@bnu.edu.cn) and M. Hu (minhu@pku.edu.cn)

Received: 18 April 2012 - Published in Atmos. Chem. Phys. Discuss.: 3 July 2012

Revised: 4 April 2013 - Accepted: 13 April 2013 - Published: 2 May 2013

\begin{abstract}
The main objective of this study is to investigate the formation and evolution mechanism of the regional haze in megacity Beijing by analyzing the process of a severe haze that occurred 20-27 September 2011. Mass concentration and size distribution of aerosol particles as well as aerosol optical properties were concurrently measured at the Beijing urban atmospheric environment monitoring station. Gaseous pollutants $\left(\mathrm{SO}_{2}, \mathrm{NO}-\mathrm{NO}_{2}-\mathrm{NO}_{\mathrm{x}}, \mathrm{O}_{3}, \mathrm{CO}\right)$ and meteorological parameters (wind speed, wind direction, and relative humidity) were simultaneously monitored. Meanwhile, aerosol spatial distribution and the height of planetary boundary layer (PBL) were retrieved from the signal of satellite and LIDAR (light detection and ranging). Concentrations of NO, $\mathrm{NO}_{2}, \mathrm{SO}_{2}, \mathrm{O}_{3}$, and $\mathrm{CO}$ observed during 23-27 September had exceeded the national ambient air quality standards for residents. The mass concentration of $\mathrm{PM}_{2.5}$ gradually accumulated during the measurement and reached at $220 \mathrm{\mu g} \mathrm{m}^{-3}$ on 26 September, and the corresponding atmospheric visibility was only $1.1 \mathrm{~km}$. The daily averaged AOD in Beijing increased from $\sim 0.16$ at $\lambda=500 \mathrm{~nm}$ on 22 September and reached $\sim 3.5$ on 26 September. The key factors that affected the formation and evolution of this haze episode were stable anti-cyclone synoptic conditions at the surface, decreasing of the height of PBL, heavy pollution emissions from urban area, number and size evolution of aerosols, and hygroscopic
\end{abstract}

growth for aerosol scattering. This case study may provide valuable information for the public to recognize the formation mechanism of the regional haze event over the megacity, which is also useful for the government to adopt scientific approach to forecast and eliminate the occurrence of regional haze in China.

\section{Introduction}

Airborne aerosols, such as sulfate, nitrate, ammonium, particulate organic matter, black carbon, and other chemical species, can scatter and absorb the incident light and therefore lead to atmosphere opacity and horizontal visibility degrade. When the horizontal visibility is equal to or less than $10 \mathrm{~km}$ and atmospheric relative humidity $(\mathrm{RH})$ is equal to or less than $90 \%$, this phenomenon is called atmospheric haze (Wu et al., 2006). Haze is pollution of fine particles in nature, fine particles are mainly from industrial emissions, vehicle exhaust pollutants, and secondary aerosols formed through a series of photochemical reactions. Haze has adverse effects on human health (Yadav et al., 2003; Xiao et al., 2006; Bell et al., 2011). Haze, rich in toxic and hazardous substances, can directly enter the human body through the respiratory system and adhere to the upper and lower respiratory tract and lungs, 
which ultimately causes respiratory and cardiovascular diseases (Tie et al., 2009). In addition, haze that reduces visibility and could directly affect the land, sea and air traffic safety (Wu et al., 2005; Mukherjee and Viswanathan, 2001). Haze has also been found to have impact on natural and agricultural ecosystems. For example, haze, a higher concentration of atmospheric particles absorbing and scattering the incident sunlight, results in the decreasing intensity of solar radiation and sunshine hours, thus, leading to the reduction of agricultural production and disruption of ecosystems (Chameides et al., 1999).

Historically, the haze occurred in some areas of the United Kingdom and the United States due to their developed economies (McNulty, 1968; Lee, 1983; Schichtel et al., 2001). Recently, haze frequently has occurred in the regions of North Africa, Indian Ocean, and Asia (Quinn and Bates, 2003; Huebert et al., 2003). Scientists throughout the world have carried out many experiments to understand the formation mechanism of haze and governments have taken effective measures to reduce the occurrence of haze (Huebert et al., 2003; Wu et al., 2005; Malm and Day, 2001; Wang et al., 2006). The United States carried out observations of atmospheric visibility and launched a large-scale visibility observation program IMPROVE (Interagency Monitoring of Protected Visual Environment Program), which established a visibility monitoring network in 1988 (Malm and Day, 2001). Furthermore, the United States developed and adopted Regional Haze Rule in 1999 (http://www.epa.gov/) calling for state and federal agencies to work together to improve visibility. Also in 1999, scientists found that the northern Indian Ocean, South and Southeast Asia were shrouded by the atmospheric brown haze during the INDOEX (Indian Ocean Experiment) (Quinn et al., 2002).

In the past $30 \mathrm{yr}$, with the rapid economic and social development, many cities in China have suffered from air pollution and extreme haze because of heavy dispersion of air pollutants (Wu et al., 2006). When haze happens, the sky seems cloudy, blurry and poorly visibility to the people. Recent haze episodes are characterized by increasing frequencies, longer duration and expanding sphere (Wu et al., 2005; Zhang et al., 2008; Kang et al., 2013). Haze, as well as its adverse effect, is one of the most concerned problems in China, and it has become the major air quality issue at the moment. There are four major haze polluted areas in China: Jing-JinTang Region, the Yangtze River delta, Sichuan Basin and the Pearl River delta (PRD), among which, the PRD is the area coupled with the most frequently occurring haze episodes. Taking Guangzhou, the central city in PRD as an example, the number of haze days was 70 in 2001; 83 days in 2002; 93 days in 2003; 144 days in 2004 (Wu et al., 2006; Deng et al., 2008). An extreme haze event happened on 2 November 2003 in Guangzhou with the instantaneous visibility value less than $200 \mathrm{~m}$, reported by $\mathrm{Wu}$ et al. (2005). Low visibilities due to aerosol pollution and high $\mathrm{RH}$ have been also observed in Xinken and Guangzhou during two PRD campaigns (Cheng et al., 2006, 2008a,b; Liu et al., 2008). The number of hazy day in Beijing urban area was 17 days in 1971, sharply grew to 223 days in 1982, and kept this level ( 200 days) until 1998 (Yang, 2008). Since 1998, Beijing had vigorously implemented a number of measures focusing on management of coal, motor vehicles, industrial and dust pollution to improve air quality (Sun et al., 2004). As a result, the hazy days quickly decreased to 73 days in 2005. But, in 2011, the haze in megacity Beijing had increased in intensity, and this extreme heavy haze could have significantly adverse effects on human health.

Haze has been studied by scientists home and abroad during the past two decades (Chen et al., 2003; Du et al., 2011; Kang et al., 2013; Sun et al., 2006; Wu et al., 2005, 2006). Chen et al. (2003) studied the formation and evolution mechanism of summertime haze in the mid-Atlantic region and signified the role of stationary weather conditions, $\mathrm{RH}$ in the haze formation and also clarified that secondary aerosol ammoniated sulfate $\left(\left(\mathrm{NH}_{4}\right)_{2} \mathrm{SO}_{4}\right.$ and $\left.\mathrm{NH}_{4} \mathrm{HSO}_{4}\right)$ was most responsible for summertime haze at this locale. IMPROVE results suggested that haze is often regional in nature (Malm and Day, 2001). However, the formation and evolution of a haze is complicated, involving the formation, growth, transport, and dispersion of aerosols (Chen et al., 2003). Most of haze has occurred in the developed region in China and resulted from excess particulate matter emitted by anthropogenic sources and gas to particle conversion (Sun et al., 2006; Wu et al., 2005; Wang et al., 2006; Du et al., 2011). Regional haze has happened frequently especially during cold winter and spring seasons because of the enhanced heating/traffic/industrial emissions with the stable synoptic conditions (Wang et al., 2006; Sun et al., 2006). Du et al. (2011) classified the haze happening in Shanghai in summertime as biomass burning induced, complicated, and from secondary pollution according to its formation mechanism. But, duststorms, which mostly happen in northern China in spring season, is a special haze due to the transported dust with high wind speed. However, available studies on the haze mostly focused on the chemical compositions of aerosols and scarcely on the formation and evolution mechanism of the haze (Sun et al., 2006; Wu et al., 2005; Wang et al., 2006; Du et al., 2011; Cheng et al., 2006, 2008a,b; Liu et al., 2008). Therefore, studies on the formation and evolution mechanism of regional haze would be useful for air quality forecast and would provide scientific support for the government to take effective measures to reduce the incidence of regional haze.

\section{Experiment}

\subsection{Experiment site}

The measurements were carried out in Beijing, the capital of the People's Republic of China, and the national center for 
politics, culture, and international business. The city's population is 36 million and its population density is 7837 people per $\mathrm{km}^{2}$ as of 2010, more than the densely populated Greater London (5437 people per $\mathrm{km}^{2}$ ) and Tokyo (5984 people per $\mathrm{km}^{2}$ ) (http://cn.chinagate.cn/population/2011-07/18/ content_23015074.htm). Furthermore, the total energy consumption is 69.5 million tons of standard coal, and there are more than 4.8 million cars in Beijing as of 2010 (http://www. bjstats.gov.cn/nj/main/2011-tjnj/index.htm). High degrees of population density and economic level had unavoidably resulted in heavy emission of air pollutants in Beijing.

Field measurements from 20-27 September were carried out at the Peking University (PKU) urban atmospheric environment monitoring station $\left(39.98^{\circ} \mathrm{N}, 116.35^{\circ} \mathrm{E}\right)$, which lies in the northwestern part of Beijing and is $\sim 600 \mathrm{~m}$ to the north of the 4th ring road that acts as one of the main traffic lines of Beijing. The observation site is located on the roof of a six-floor building ( $\sim 20 \mathrm{~m}$ a.g.l. - above ground level), all of the instruments were installed in an air-conditioned room except the visibility sensor, which was installed outdoors. Possible air pollutants sources arriving at measurement site were local vehicular traffic, combustion of fuels for cooking, and some of the transported pollutants.

\subsection{Measurements}

The instruments involved in this study are listed in Table 1. Mass concentration of $\mathrm{PM}_{2.5}$ (particulate matter with aerodynamic diameter less than $2.5 \mu \mathrm{m}$ ) was monitored by TEOM (tapered element oscillating microbalance). Gaseous pollutants $\left(\mathrm{SO}_{2}, \mathrm{NO}-\mathrm{NO}_{2}-\mathrm{NO}_{\mathrm{x}}, \mathrm{O}_{3}, \mathrm{CO}\right)$ were detected by i-series automatic monitoring system manufactured by Thermo Electron Corporation (USA). Meteorological parameters including wind speed, temperature and RH were measured by the automatic meteorological station. Particle size distribution was measured by SMPS (Scanning Mobility Particle Sizers) and APS (Aerodynamic particle sizer) (Liu et al., 2008). The SMPS spectrometer is a system that measures the particle number size distribution in the size range from 2.5 to $1000 \mathrm{~nm}$. Particles of different sizes were classified with differential mobility analyzer (DMA, Hauke-type), and their concentrations were measured with a condensation particle counter (CPC, TSI Model 3010). The APS measured particle size distributions with aerodynamic diameters from 0.5 to $20 \mu \mathrm{m}$.

The nephelometer continuously measured the light scattering coefficient by dry particles $b_{\mathrm{sp}}$ (dry) at a wavelength of $532 \mathrm{~nm}$. A silicone tube drier maintained the RH of the pumped air less than $30 \%$ during the field study. The nephelometer was routinely calibrated by zero and span check. The nephelometer correction factor for truncation error had been done by Liu et al. (2008). The MAAP (Petzold and Schonlinner, 2004) operated at the incident light wavelength of $670 \mathrm{~nm}$ on the principle of light attenuation due to absorption by aerosols deposited on the quartz fiber filter. Aerosol absorption coefficient $b_{\text {ap }}$ was then calculated by the product of mass concentration of $\mathrm{BC}$ by specific absorption coefficient $\left(6.6 \mathrm{~m}^{2} \mathrm{~g}^{-1}\right)$, which was from the manufacture guide. Spectral aerosol optical depth (AOD) was measured by a 5channel $(380,500,675,870$, and $1020 \mathrm{~nm})$ handheld sunphotometer (Microtops II, USA). The instrument is equipped with five accurately aligned optical collimators. Each channel is fitted with a narrow-band interference filter and a photodiode suitable for the particular wavelength range. Radiation captured by the collimator and filters onto the photodiodes produces an electrical current that is proportional to the radiant power. AOD is determined by the Bouguer-LambertBeer law. Additionally, in order to investigate the sources of the regional haze from a large scale, spatial distribution of AOD with $10 \mathrm{~km} \times 10 \mathrm{~km}$ resolution was retrieved from the remote sensing data of the Moderate Resolution Imaging Spectroradiometer (MODIS) on Terra and Aqua satellites (http://modis-atmos.gsfc.nasa.gov/).

Visibility sensor system consisted of a transmitter, a receiver, and a controller. It measured the light extinction of infrared light $(\lambda=875 \mathrm{~nm})$ in air, and the measurement range was from $10 \mathrm{~m}$ to $50 \mathrm{~km}$. It should be noted that the wavelengths that the optical instruments used were different; therefore, all parameters were scaled to values at the wavelength of $550 \mathrm{~nm}$ by using a power-law wavelength dependence (i.e., with the help of Ångström exponents that were retrieved from the spectral distribution of AOD). The measured value of visibility (Vis) was directly transformed to atmospheric extinction coefficient $b_{\text {ext }}(\mathrm{RH})$ at $550 \mathrm{~nm}$ in unit of inverse megameter $\left(\mathrm{M} \mathrm{m}^{-1}\right)$ by Eq. (1) (Koschmieder, 1924; Seinfeld and Pandis, 2006):

$b_{\text {ext }}(\mathrm{RH})=\frac{3.912 \times 10^{3}}{\text { Vis }} \times\left(\frac{550}{\lambda}\right)$.

The LIDAR (light detection and ranging), being similar to that reported by Sugimoto et al. (2009), was installed in the institute of atmospheric physics (IAP), Chinese academy of sciences $\left(39.98^{\circ} \mathrm{N}, 116.37^{\circ} \mathrm{E}\right)$, about $5.7 \mathrm{~km}$ east of Peking University. The same conditions of PBL were assumed at these two nearby measurement sites. The LIDAR was designed for automated continuous operation and was directed vertically. The LIDAR was operated for $5 \mathrm{~min}$ every $15 \mathrm{~min}$, and the averaged profile data were stored. Therefore, 96 profiles were recorded per day. The LIDAR had a $25 \mathrm{MHz}$ analog-to-digital conversion rate, which means a $6 \mathrm{~m}$ height resolution. LIDAR signals were processed with range corrected and overlap corrected, and then the calibrated signals could be used to retrieve the height of planetary boundary layer (PBL). Several methods, including threshold techniques (Melfi et al., 1985) and gradient techniques (Hayden et al., 1997), have been investigated to extract the PBL height from LIDAR data. The fundamental premise took advantage of the large variance in aerosol echo profile where the aerosol concentration changed abruptly between the free troposphere and mixing layer. In this study, we used the coefficient of 
Table 1. Overview of instruments involved in this study.

\begin{tabular}{|c|c|c|c|c|}
\hline Instrument & Parameter & $\begin{array}{l}\text { Manufacturer } \\
\text { model }\end{array}$ & Calibration & $\begin{array}{l}\text { Wavelength } \\
(\mathrm{nm})\end{array}$ \\
\hline TEOM & $\mathrm{PM}_{2.5}$ & $\begin{array}{l}\text { Thermo. Electron. } \\
1400 \mathrm{a}\end{array}$ & - & - \\
\hline $\begin{array}{l}\text { Pulsed fluorescence } \\
\mathrm{SO}_{2} \\
\text { analyzer }\end{array}$ & $\mathrm{SO}_{2}$ & $\begin{array}{l}\text { Thermo. Electron. } \\
\text { 43iTL }\end{array}$ & $\begin{array}{l}\text { Zero, span check } \\
\text { every day }\end{array}$ & - \\
\hline $\begin{array}{l}\text { Chemiluminescence } \\
\mathrm{NO}-\mathrm{NO}_{2}-\mathrm{NO}_{\mathrm{x}} \\
\text { analyzer }\end{array}$ & $\mathrm{NO}-\mathrm{NO}_{2}-\mathrm{NO}_{\mathrm{x}}$ & $\begin{array}{l}\text { Thermo. Electron. } \\
42 \mathrm{iTL}\end{array}$ & $\begin{array}{l}\text { Zero, span check } \\
\text { every day }\end{array}$ & - \\
\hline $\begin{array}{l}\mathrm{UV} \text { photometric } \mathrm{O}_{3} \\
\text { analyzer }\end{array}$ & $\mathrm{O}_{3}$ & $\begin{array}{l}\text { Thermo. Electron. } \\
49 \mathrm{i}\end{array}$ & $\begin{array}{l}\text { Zero, span check } \\
\text { every day }\end{array}$ & - \\
\hline $\begin{array}{l}\text { Gas filter correlation } \\
\mathrm{CO} \text { analyzer }\end{array}$ & $\mathrm{CO}$ & $\begin{array}{l}\text { Thermo. Electron. } \\
\text { 48iTL }\end{array}$ & $\begin{array}{l}\text { Zero, span check } \\
\text { every day }\end{array}$ & - \\
\hline $\begin{array}{l}\text { Wind speed } \\
\text { temperature/RH sensor }\end{array}$ & $\begin{array}{l}\text { Wind speed, } \\
\text { Temperature, RH }\end{array}$ & $\begin{array}{l}\text { Vaisala } \\
\text { GMT220 } \\
\text { HMP45 }\end{array}$ & - & - \\
\hline SMPS & $\begin{array}{l}\text { Particle size } \\
\text { distribution } \\
(2.5 \sim 1000 \mathrm{~nm})\end{array}$ & $\begin{array}{l}\text { TSI Com. } \\
3936\end{array}$ & - & - \\
\hline APS & $\begin{array}{l}\text { Particle size } \\
\text { distribution } \\
(0.5 \sim 20 \mu \mathrm{m})\end{array}$ & $\begin{array}{l}\text { TSI Com. } \\
3321\end{array}$ & - & - \\
\hline $\begin{array}{l}\text { Integrating } \\
\text { nephelometer }\end{array}$ & $\begin{array}{l}\text { Aerosol } \\
\text { scattering } \\
\text { coefficient }\end{array}$ & $\begin{array}{l}\text { Ecotech } \\
\text { M9003 }\end{array}$ & $\begin{array}{l}\text { Zero, span check }\left(\mathrm{CO}_{2}\right) \\
\text { every day }\end{array}$ & 525 \\
\hline MAAP & $\begin{array}{l}\text { Aerosol } \\
\text { absorption } \\
\text { coefficient }\end{array}$ & $\begin{array}{l}\text { Thermo. Electron. } \\
\text { Caruso } 5012\end{array}$ & $\begin{array}{l}\text { Zero, flow-rate check } \\
\text { at the start/end }\end{array}$ & 670 \\
\hline Sun-photometer & $\begin{array}{l}\text { Aerosol optical } \\
\text { depth }\end{array}$ & $\begin{array}{l}\text { Solar light Inc. } \\
\text { Microtops II }\end{array}$ & - & $\begin{array}{l}380,500,675 \\
870,1020\end{array}$ \\
\hline Visibility meter & $\begin{array}{l}\text { Atmospheric } \\
\text { extinction } \\
\text { coefficient }\end{array}$ & $\begin{array}{l}\text { Vaisala } \\
\text { FD12 }\end{array}$ & $\begin{array}{l}\text { Before and after } \\
\text { the campaign }\end{array}$ & 875 \\
\hline LIDAR & PBL height & NIES* & - & 525 \\
\hline
\end{tabular}

* NIES: National Institute for Environmental Studies, Japan.

variance of LIDAR signals calculated by Eq. (2) to detect the height of the PBL (Strawbridge and Snyder, 2004):

$v=\frac{S}{\bar{x}} \times 100 \%=\frac{\sqrt{\frac{\sum_{i=1}^{n}\left(x_{i}-\bar{x}\right)^{2}}{n}}}{\frac{1}{n} \sum_{i=1}^{n} x_{i}} \times 100 \%$

where $S$ is standard deviation and $\bar{x}$ is the average of adjacent five LIDAR signals, which were from the normalized backscattering data on $532 \mathrm{~nm}$ wavelength channel. The site where its coefficient of variance is the maximum is the height of the PBL.

\section{Results and discussion}

\subsection{Process of regional haze}

\subsubsection{Temporal variations of atmospheric pollutants}

Temporal variations of measured $\mathrm{NO}, \mathrm{NO}_{2}, \mathrm{SO}_{2}, \mathrm{O}_{3}, \mathrm{CO}$, and $\mathrm{PM}_{2.5}$ in Beijing from 20-27 September 2011 are depicted in Fig. 1. Generally, the concentrations of air pollutants $\mathrm{NO}_{2}, \mathrm{SO}_{2}, \mathrm{CO}$, and $\mathrm{PM}_{2.5}$ had an increasing trend, with the exception of $\mathrm{NO}$, probably due to the scavenging process by $\mathrm{O}_{3} . \mathrm{O}_{3}$, which is formed by photochemical reactions between volatile organic compounds (VOCs) and nitrogen oxides $\left(\mathrm{NO}_{\mathrm{x}}\right)$ in the presence of heat and sunlight (Seinfeld 


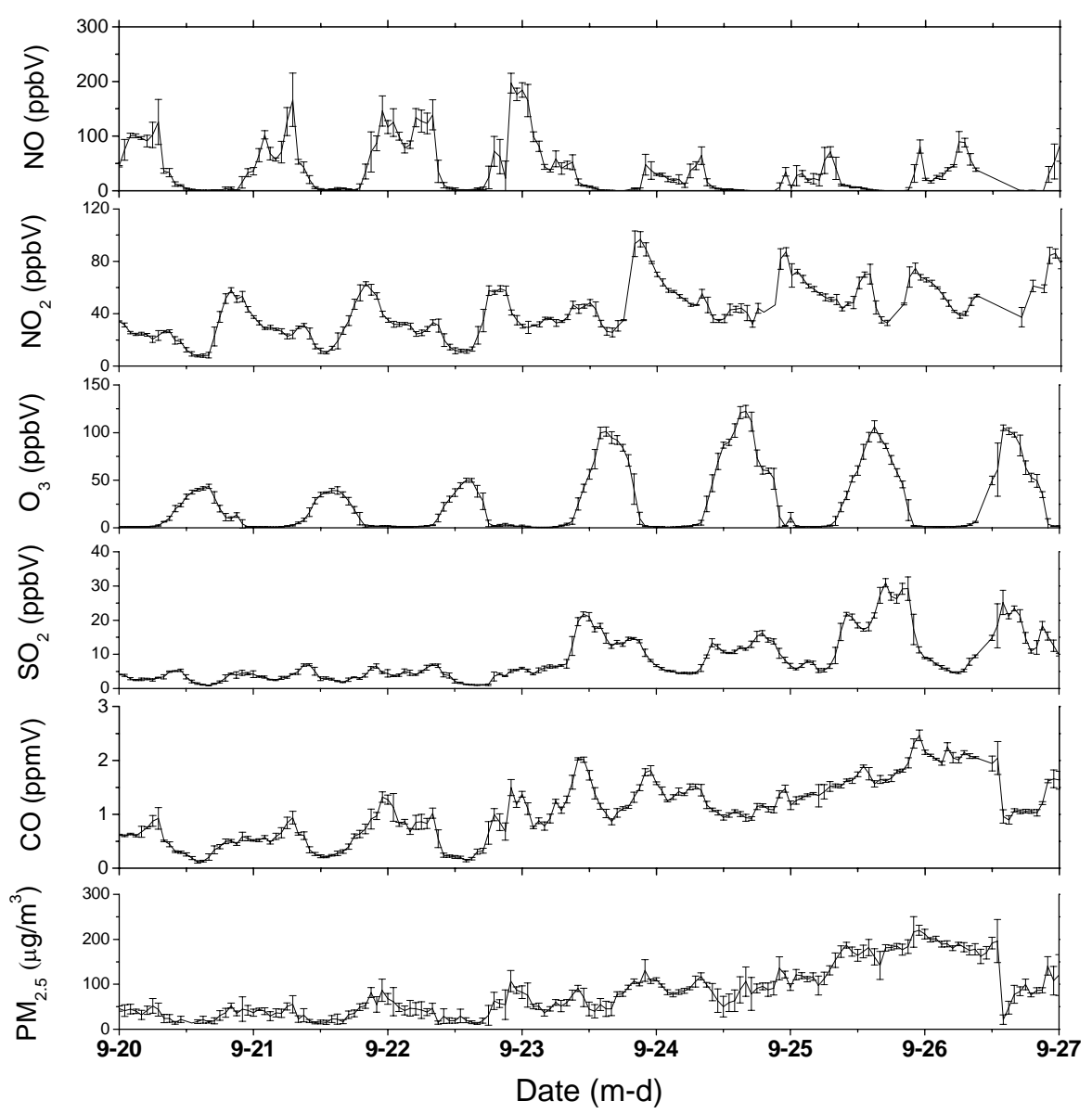

Fig. 1. Time series of observed $\mathrm{NO}, \mathrm{NO}_{2}, \mathrm{SO}_{2}, \mathrm{O}_{3}, \mathrm{CO}$, and $\mathrm{PM}_{2.5}$ in Beijing from 20-27 September 2011.

and Pandis, 2006), also showed an increasing trend until 24 September with a slight decrease on 25 and 26 September. $\mathrm{O}_{3}$ concentration in this pollution episode exceeded $100 \mathrm{ppbV}$ and reached $120 \mathrm{ppbV}$ on 24 September, which was higher than the national ambient air quality standards for $\mathrm{O}_{3}\left(93 \mathrm{ppbV}\right.$ ) (i.e., China air quality standard $200 \mu \mathrm{g} \mathrm{m}^{-3}$ ). Pollutants $\mathrm{SO}_{2}, \mathrm{NO}_{2}$ and $\mathrm{CO}$, being the emissions from biomass, fuel and coal burning, had the same increasing trend from 20-27 September. The mass loading of $\mathrm{PM}_{2.5}$ gradually accumulated, and its instantaneous value reached at $220 \mu \mathrm{g} \mathrm{m}^{-3}$ at midnight of 26 September and daily average was $143 \mu \mathrm{g} \mathrm{m}^{-3}$ on 26 September, which was nearly 4 times as high as the daily limit $\left(35 \mu \mathrm{g} \mathrm{m}^{-3}\right)$ of the USA Ambient Air Quality Standard. Sun et al. (2004) monitored an extreme $\mathrm{PM}_{2.5}$ concentration with $349 \mu \mathrm{g} \mathrm{m}^{-3}$ in winter from 2002 to 2003, and He et al. (2001) monitored an extreme $\mathrm{PM}_{2.5}$ concentration with $357 \mu \mathrm{g} \mathrm{m}^{-3}$ in Beijing from July 1999 to September 2000. Concentrations of $\mathrm{NO}, \mathrm{NO}_{2}, \mathrm{SO}_{2}, \mathrm{O}_{3}, \mathrm{CO}$, and $\mathrm{PM}_{2.5}$ observed during 23-27 September had exceeded the national ambient air quality standards for residents, indicating that air pollution had been very serious, and such a high value of $\mathrm{PM}_{2.5}$ was regularly considered unsuitable for residents.

\subsubsection{Temporal variations of atmospheric optical properties}

Figure 2 shows the temporal series of observed aerosol scattering coefficient $b_{\mathrm{sp}}$, aerosol absorption coefficient $b_{\mathrm{ap}}$, absorption coefficient by $\mathrm{NO}_{2} b_{\mathrm{ag}}$, atmospheric extinction coefficient $b_{\text {ext }}(\mathrm{RH})$, and atmospheric visibility in Beijing from 20-27 September 2011. Absorption coefficient by $\mathrm{NO}_{2} b_{\mathrm{ag}}$ was calculated by experiential equation $b_{\mathrm{ag}}=0.33 \cdot\left[\mathrm{NO}_{2}\right]$ from Hodkinson (1966). $b_{\mathrm{sp}}, b_{\mathrm{ap}}$, and $b_{\mathrm{ext}}(\mathrm{RH})$ had the same tendency to increase in the formation process of haze. Furthermore, the value of $b_{\text {ext }}(\mathrm{RH})$ was nearly $5600 \mathrm{M} \mathrm{m}^{-1}$ in the morning of 26 September and the corresponding visibility was only $1.1 \mathrm{~km} . b_{\mathrm{ag}}$ also had an increasing trend with apparent diurnal variation. The visibility decreased sharply from 23 September and met the definition of haze (Vis $\leq 10 \mathrm{~km}$ and $\mathrm{RH} \leq 90 \%$ ). Furthermore, as illustrated in Fig. 3, the value of daily averaged AOD at Beijing urban area increased from $\sim 0.16$ at $\lambda=500 \mathrm{~nm}$ on 22 September and reached $\sim 3.5$ on 26 September; the value of AOD increased nearly 22 times from clear day to haze day, and about 17 times larger than that (0.195) of the global mean value of AOD over land studied by Bevan et al. (2012). 

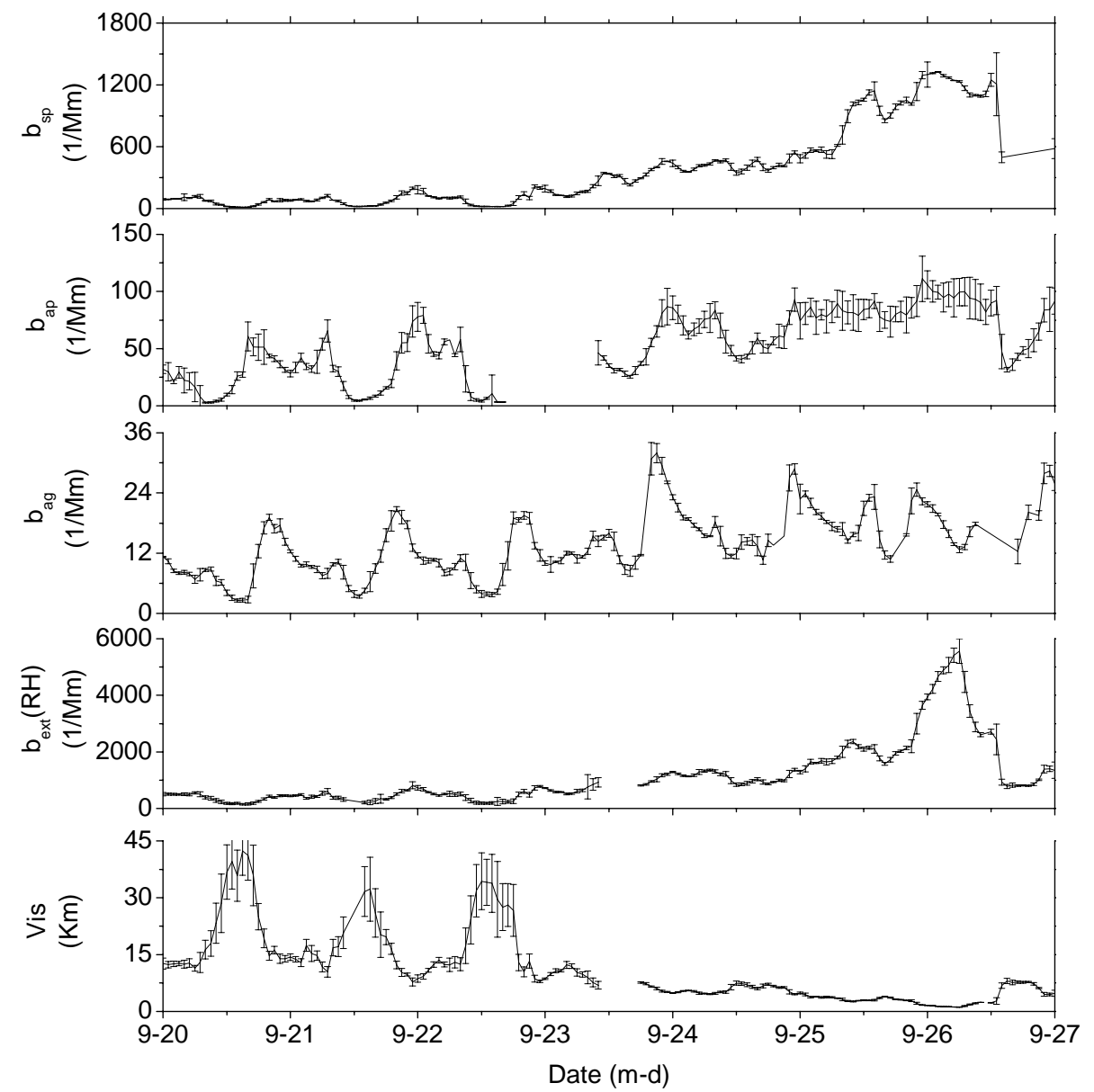

Fig. 2. Time series of measured aerosol scattering coefficient $b_{\mathrm{sp}}$, aerosol absorption coefficient $b_{\mathrm{ap}}$, absorption coefficient by $\mathrm{NO}_{2} b_{\mathrm{ag}}$, atmospheric extinction coefficient $b_{\text {ext }}(\mathrm{RH})$, and atmospheric visibility (Vis) in Beijing from 20-27 September 2011.

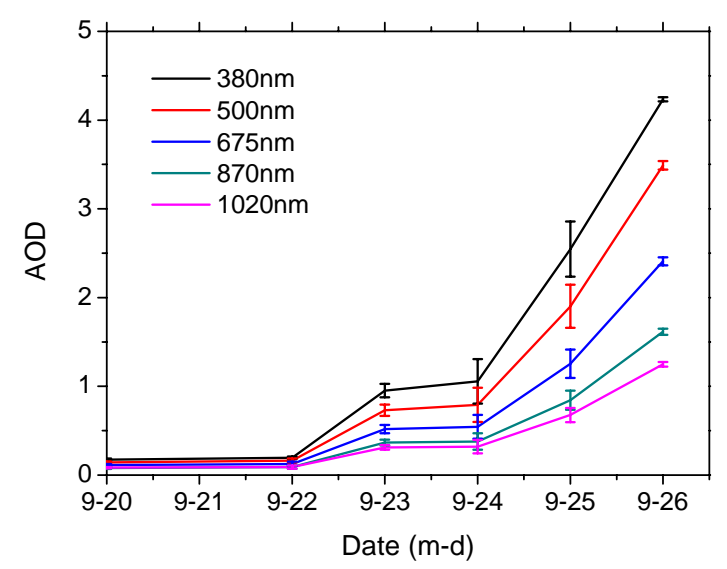

Fig. 3. Temporal series of daily averaged aerosol optical depth measured by sunphotometer in Beijing.

\subsection{Formation and evolution mechanism of regional haze}

\subsubsection{Stable synoptic condition}

The surface weather maps at 05:00 LT from 22-25 September are shown in Fig. 4. A slowly migrating anti-cyclone (high-pressure system) which resulted in clear sky, subsidence airflow, and relatively stagnant conditions (Chen et al., 2003) overlaid Beijing-Tianjin-Tangshan Region before 23 September. The edge of a slowly migrating cyclone (which originated in northeastern China) affected Beijing area from 24 September and possibly caused a build-up of pollutants in this region. Beijing area was again controlled by the edge of the high-pressure system from 25 September. Beijing-Tianjin-Tangshan Region was dominated by weak high pressure, indicating fine weather. From China's Fengyun-2 satellite image (http://www.nmc.gov.cn/publish/ satellite/fy2.htm) (showed by example in Fig. 5), there was no cloud over Beijing-Tianjin-Tangshan Region and it provided favorable conditions for photochemical reactions. 


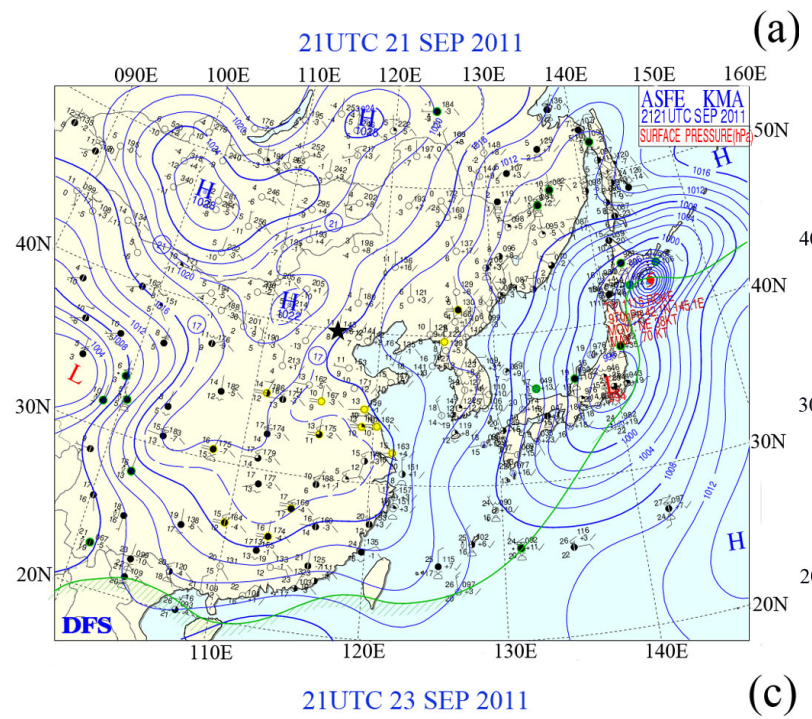

(a)

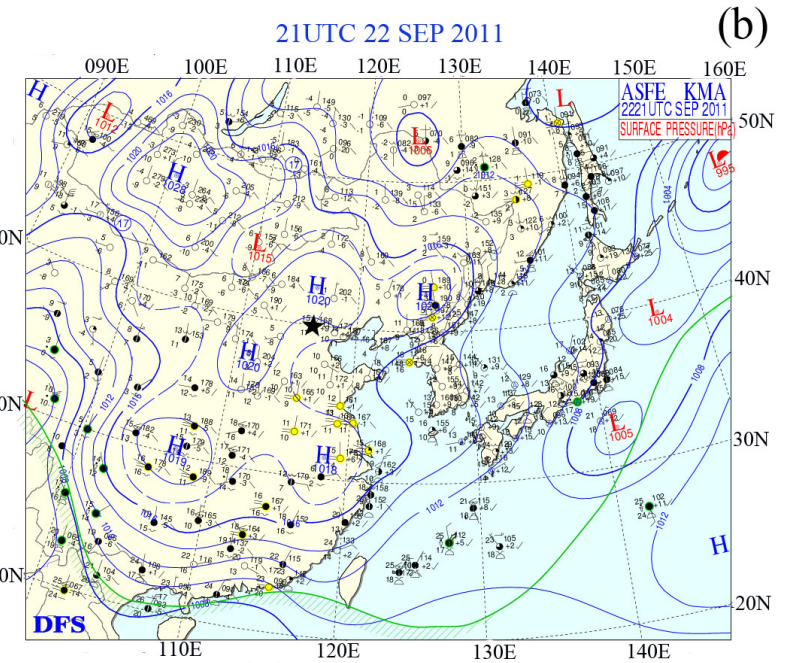

(c)
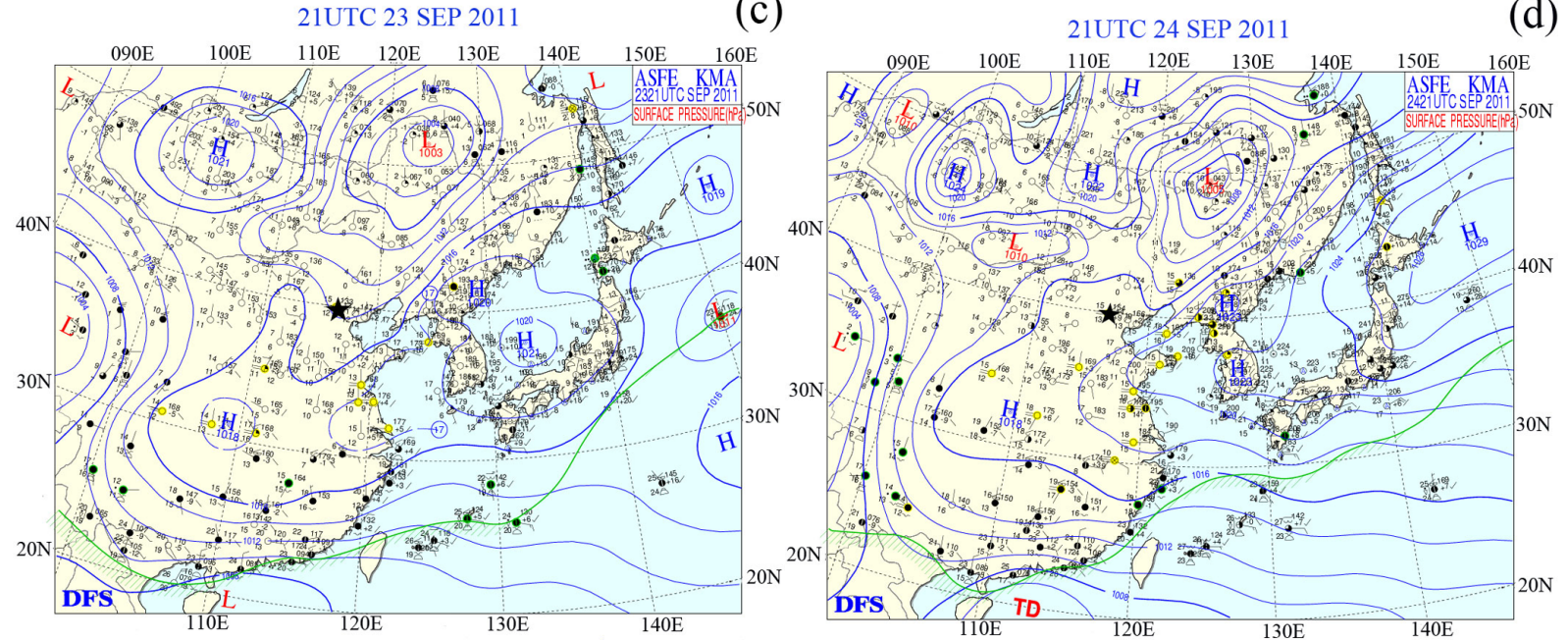

(d)

Fig. 4. Weather maps on the surface at (a) 05:00 LT 22 September, (b) 05:00 LT 23 September, (c) 05:00 LT 24 September, and (d) 05:00 LT 25 September. Black star denotes measurement site.

Dominance of high pressure in the Beijing-Tianjin-Tangshan Region also indicated aloft airflow convergence and surface divergence. Due to the divergence of the air around the anticyclone, the airflow would subside and restrict the development of the height of the PBL, which limited the vertical diffusion of pollutants (discussed in Sect. 3.2.2).

Furthermore, because there were no strong pressure gradients over Beijing-Tianjin-Tangshan Region in Fig. 4, large scale air circulation was relatively weak due to low wind speed. This stable synoptic condition and calm wind favored the accumulation of the atmospheric pollutants and horizontal dilution was difficult, ultimately led to high concentrations of urban pollutants. As depicted in Fig. 6a, the wind speed was relatively low with the mean value of $0.9 \mathrm{~m} \mathrm{~s}^{-1}$ from 23-26 September, which was consistent with the occurrence of haze episode. In addition, the air temperature decreased from 22 September (maximum $29.7^{\circ}$ ) to 23 September (maximum $25.3^{\circ}$ ), which would cause the lack of the thermal dynamics for the development of the PBL (discussed in Sect. 3.2.2). Meanwhile, the RH during 2123 September was below $60 \%$ with minimum of $10 \%$, but, its value increased with a maximum of $75-80 \%$ and a minimum of 30 40\% during 24-27 September. The ambient aerosols would uptake water vapor and grow in diameter, which also resulted in higher light scattering (discussed in Sect. 3.2.5) and the formation of this haze event.

During this haze episode, Beijing-Tianjin-Tangshan Region was dominated by a weak high pressure system with low wind speed, subsidence airflow, and shallow PBL, which restricted the diffusion of pollutants in the vertical and horizontal directions. So, stable synoptic condition was one of the important factors resulting in the formation and evolution of haze event. Wu et al. (2005) studied an extreme haze episode over the Guangzhou region of China and also clarified that descending air motion and weak horizontal wind produced very high aerosol concentrations. Fu et al. (2008) 


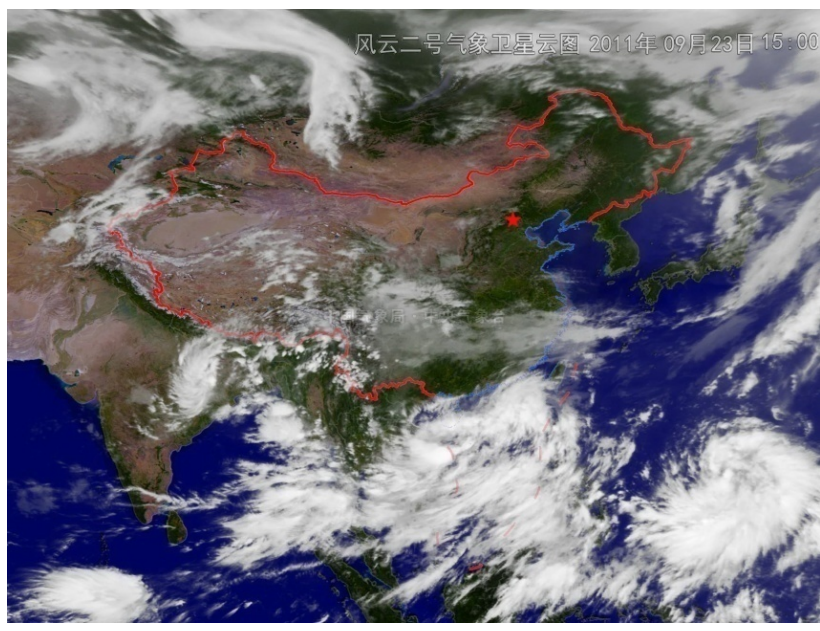

Fig. 5. Example of satellite maps during haze. Red star denotes measurement site.

stated that the stagnant dispersion conditions caused by the surface high pressure played the predominant role in causing high pollution over the Yangtze River delta of China.

\subsubsection{Decreasing of the height of PBL}

The height of PBL was an important parameter, which determined the height of vertical dispersion of air pollutants emitted from the surface of the Earth (Kim et al., 2007). Low height of PBL would retain the pollutants in the surface layer and made the city shrouded by haze. Figure 7 is the time-height indication of the normalized LIDAR backscatter signal (in arbitrary units) at $532 \mathrm{~nm}$ and the black line is the height of PBL. At midday from 20-22 September, the height of PBL was about $1.7 \mathrm{~km}$, the height of PBL was about $1.5 \mathrm{~km}$ on 23 September, and became $1 \mathrm{~km}$ on 24 September, and $0.75 \mathrm{~km}$ on 25 September.

Large scale weak high pressure moved over the BeijingTianjin-Tangshan Region as described in Sect. 3.2.1 and subsidence airflow restricted the development of the height of the PBL. Meanwhile, the development of the PBL was driven by thermal (air temperature) and dynamic (wind speed) factor from the local perspective. On the one hand, lower temperature on 23 September (as shown in Fig. 6c) was not conducive to the development of the PBL. On the other hand, low wind speed and thus low entrainment also restricted the development of the PBL.

With the decrease of the height of PBL, the pollutants in the PBL were "compressed" to a shallow layer and the contamination on the ground significantly increased. In Fig. 7, the red color indicates heavy aerosol pollution, aerosol mass concentration was increasing with the decreasing PBL height. The height of the PBL on 25 September $(0.75 \mathrm{~km})$ was half of the height of the PBL on 23 September $(1.5 \mathrm{~km})$, and the mass concentration of $\mathrm{PM}_{2.5}$ on 25 September $\left(156.5 \pm 35.9 \mu \mathrm{g} \mathrm{m}^{-3}\right)$ was 2.3 times of that

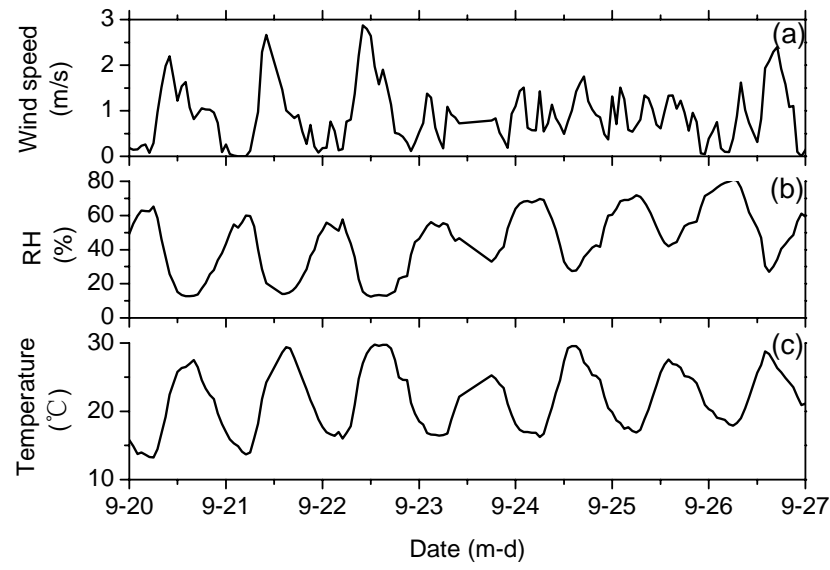

Fig. 6. Time series of meteorological parameter in Beijing from 20 27 September 2011.

$\left(69.7 \pm 25.3 \mu \mathrm{g} \mathrm{m}^{-3}\right)$ on 23 September. Furthermore, the solar energy arriving at the earth was decreasing with the aerosol accumulated in the atmosphere and then the air temperature would drop, which was not conductive to the development of PBL. The feedback effects between the development of PBL and mass loading of aerosols in atmosphere are apparent, and their quantitative relationship is worthy of further study. Aerosols were forced into a very shallow layer due to decreasing height of PBL and lastly resulted in the formation of regional haze. That is, the height of PBL decreased, and the concentration of particles increased. Generally, such external forces as high wind or rain would be needed to interrupt the further development of this extreme air pollution episode.

The relationship between weather and air pollution was very complicated, and their relationship is an interesting scientific issue that deserved further study. Air pollution was caused by the adverse weather conditions, in other words, unfavorable weather conditions resulted in heavy air pollution. When the concentration of pollutants increased, the amount of solar radiation reaching the ground decreased, which would inevitably lead to lower surface temperature; the then PBL height reduced as well as the RH increased. All of these factors resulted in the visibility degradation. However, when the contamination was light, the sunlight reaching the ground increased and air temperature increased with lower RH and higher PBL, which favored the diffusion of pollutants, and it was not conducive to the formation of haze. Further measurements and modeling studies are needed to investigate the interaction mechanism of air pollution and meteorological conditions.

\subsubsection{High emissions of local anthropogenic pollution}

AOD was a good indicator of the mass loading of particles in the atmosphere. The AOD retrieved from the remote sensing of MODIS with the algorithm introduced by Li et al. (2005) 


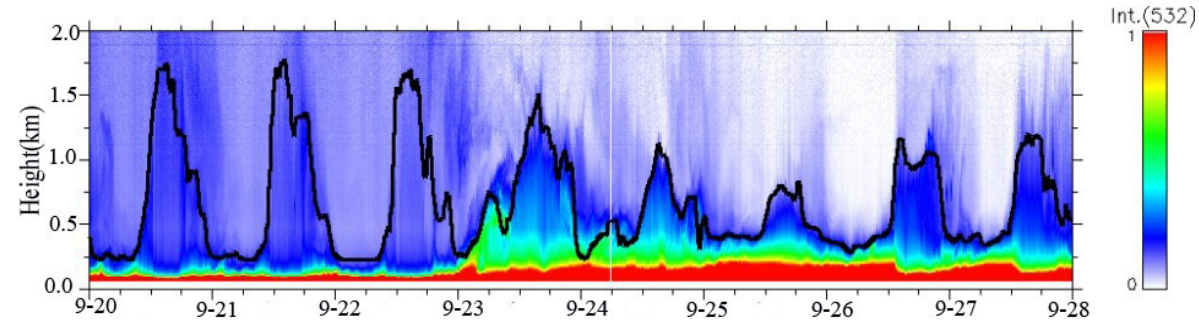

Fig. 7. Time-height indications of the normalized LIDAR backscatter signal in arbitrary units at $532 \mathrm{~nm}$. The black line is the height of the PBL.
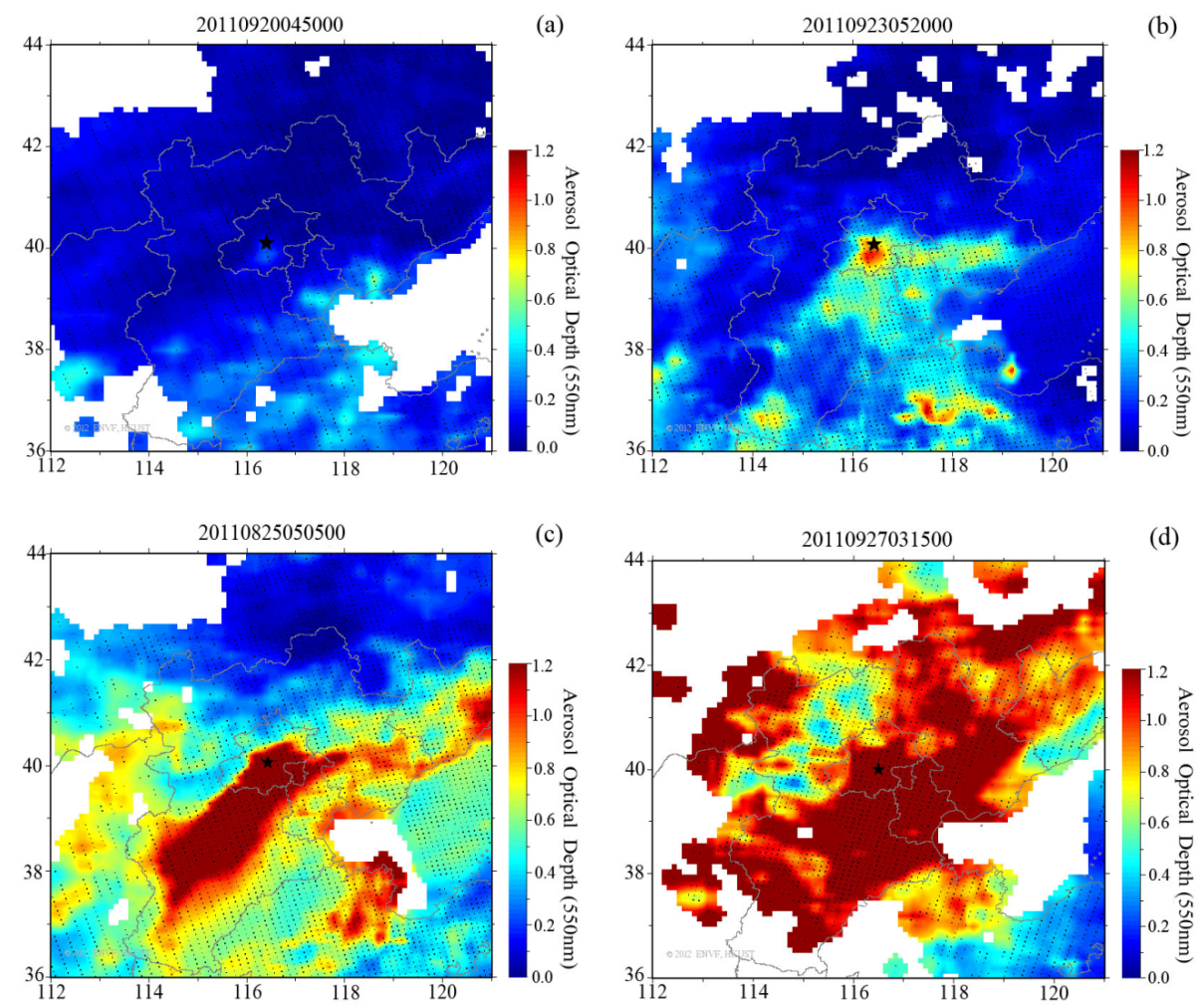

Fig. 8. Aerosol optical depth measured by MODIS on (a) 20 September, (b) 23 September, (c) 25 September, and (d) 27 September. Black star denotes measurement site.

is illustrated in Fig. 8 to depict more detailed features of the spatial distribution of particle pollutants over BeijingTianjin-Tangshan Region. The Beijing-Tianjin-Tangshan Region is an important economic core area in China and is heavily populated, urbanized, and industrialized. Compared with other cities in this region, aerosol pollution in Beijing was at a higher level on 20 September (Fig. 8a) and the particle pollutants were firstly intensified on 23 September (Fig. 8b). The divergence airflow at the ground (Sect. 3.2.1) led to a large scale aerosol outflow from Beijing to the down-wind area. According to the trend of the isobars in Fig. 4, pollutants from Beijing were diffused in the northeast-southwest direction, as seen by the increased AOD over time in Fig. 8.

As depicted in Fig. 3, the value of daily averaged AOD at $500 \mathrm{~nm}$ on 22 September was 0.16 , but its value reached 0.73 and 1.90 on 23 September and 25 September, respectively. That is, the mass loading of particles increased $\sim 3.6$ times during 22-23 September. Although the height of the PBL on 25 September was half of the height of the PBL on 23 September (as discussed in Sect. 3.2.2), the mass loading of particles on 25 September was $\sim 2.6$ times of that on 23 September. Moreover, the AOD in the upwind rural areas was smaller than that in Beijing and the inflow concentration of aerosols to Beijing was smaller. The AOD at Beijing increased sharply during the measurement (Figs. 3 and 8) implying that this haze event was partly due to the high intensity of local anthropogenic emissions. The haze originated from Beijing urban area and then expanded to the surrounding areas - Tianjin, Tangshan, and other cities - in Hebei province. Weak circulation caused a build-up of local 
pollutants in this region. In addition, the wind speed showed negative correlations with the mass concentration of $\mathrm{PM}_{2.5}$ in Beijing as discussed in Sect. 3.2.1, which indicated that this haze event was partly attributed to the high emissions of local anthropogenic pollution through direct emissions and subsequent secondary transformations.

\subsubsection{Number and size evolution of aerosols}

According to its size distribution, aerosol could be divided into nucleation mode (particles with diameters $3 \sim 25 \mathrm{~nm})$, Aitken mode ( $25 \sim 100 \mathrm{~nm})$, accumulation mode $(0.1 \sim 1 \mu \mathrm{m})$, and coarse mode $(>1 \mu \mathrm{m})$. Particle size distribution is an important factor determining the amount of visible light scattered by atmospheric aerosols. In theory, the contribution of extinction by nucleation mode and coarse mode could be ignored regarding visibility impairment, and aerosols in accumulation mode contributed most of the light extinction (Cheng et al., 2008b).

Primary gaseous species such as $\mathrm{NO}_{2}, \mathrm{SO}_{2}$ and VOCs could form secondary nitrate, sulfate and organic particles in nucleation or Aitken mode through photochemical reaction. Temporal variance of particle size distribution, $\mathrm{SO}_{2}$ mixing ratio, and $\mathrm{PM}_{2.5}$ mass concentration from 20-27 September in Beijing is illustrated in Fig. 9. Nanoparticle event (Russell et al., 2007), which is characterized by banana-shaped contour, happened on 20, 21, and 22 September (Fig. 9a). These events occurred before or during noon time when higher levels of $\mathrm{SO}_{2}$ were simultaneously observed (Fig. 9b) and $\mathrm{PM}_{2.5}$ mass concentrations were at significantly lower values than their averages (Fig. 9c). Subsequently, nanoparticles quickly grew to bigger size due to heterogeneous reactions or coagulation, and particles were mainly in the Aitken mode in the afternoon. The growth rate of nanoparticles were calculated using the method introduced by Kulmala et al. (2001), and the growth rate were $1.8,2.3$, and $3.8 \mathrm{~nm} \mathrm{~h}^{-1}$ for 20,21 , and 22 September, respectively.

Temporal variations of aerosol number concentration for nucleation mode, Atiken mode, and accumulation mode are illustrated in Fig. 10. The bursts of the nucleation mode aerosols on each day of 20-22 September were immediately followed by an increase of aerosols in Atiken mode. Aerosols growth in diameter was apparent. In the process of haze evolution during 23-26 September, the number concentration of aerosols in nucleation mode decreased and that in accumulation mode sharply increased (Fig. 10). Especially, the number concentrations of aerosols in accumulation mode $\left(8000 \mathrm{~cm}^{-3}\right)$ were larger than those in Aitken mode or nucleation mode from noon time on 25 September. Low wind speed favored accumulation of aerosols and hence aerosol surface area increased, which could favor the heterogeneous reactions at the surface of the existing aerosols. The scattering ability of these aerosols in accumulation mode was strong and resulted in the deterioration of visibility, as shown in Fig. 10 where the temporal distribution of the directly

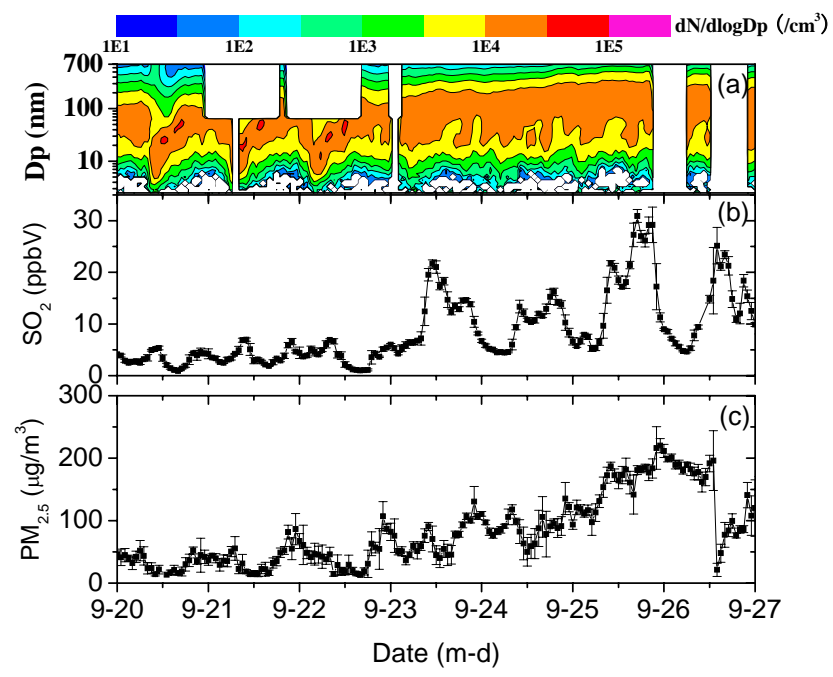

Fig. 9. Temporal variations of (a) particle size distribution, (b) $\mathrm{SO}_{2}$ mixing ratio, and (c) $\mathrm{PM}_{2.5}$ mass concentration from 20 27 September 2011. Empty space denotes lack of measurements.

measured aerosol scattering coefficients was consistent with that of aerosol number concentrations in accumulation mode.

Nanoparticle events occurred on 20-22 September, and these nanoparticles grew larger in diameter to the accumulation mode through heterogeneous reactions or coagulation during 23-26 September. With the number concentration increase of aerosols in accumulation mode as well as the increase of their sizes, light scattered by aerosols gradually increased, which led to the occurrence of haze.

\subsubsection{Impact of hygroscopic growth for aerosol scattering $f(\mathbf{R H})$}

Sulfur and nitrogen oxides could form sulfate, nitrate aerosols by gas to particle conversion in the atmosphere. Furthermore, water-soluble ions (e.g., $\mathrm{SO}_{4}^{2-}, \mathrm{NO}_{3}^{-}, \mathrm{NH}_{4}^{+}$, and $\mathrm{Na}^{+}$) accounted for $\sim 60 \%$ of the mass of $\mathrm{PM}_{10}$ in Beijing (Liu et al., 2009). When RH in the atmosphere was high, these strong hydrophilic aerosols grew in diameter due to uptake of water vapor and their ability to scatter light increased (Tang, 1996), which resulted in decreasing the atmospheric visibility. Hygroscopic factor for aerosol scattering $f(\mathrm{RH})$, being the ratio of the aerosol scattering coefficient in wet conditions to that in dry conditions, was calculated by Eq. (3) (Hegg et al., 1993; Liu et al., 2008, 2010):

$$
f(\mathrm{RH})=\frac{b_{\mathrm{sp}}(\mathrm{RH})}{b_{\mathrm{sp}}(\mathrm{dry})}=\frac{b_{\mathrm{ext}}(\mathrm{RH})-b_{\mathrm{sg}}-b_{\mathrm{ag}}-b_{\mathrm{ap}}}{b_{\mathrm{sp}}(\mathrm{dry})},
$$

where, "s" and "a" denote scattering and absorption, and "p" and "g" denote particle and gas, respectively.

Figure 11 shows the ratio of wet to dry light scattering acting as a function of RH. The $f(\mathrm{RH})$ had the tendency to increase with increasing RH. Usually, the relationship between $f(\mathrm{RH})$ and $\mathrm{RH}$ could be fitted by empirical functions: 


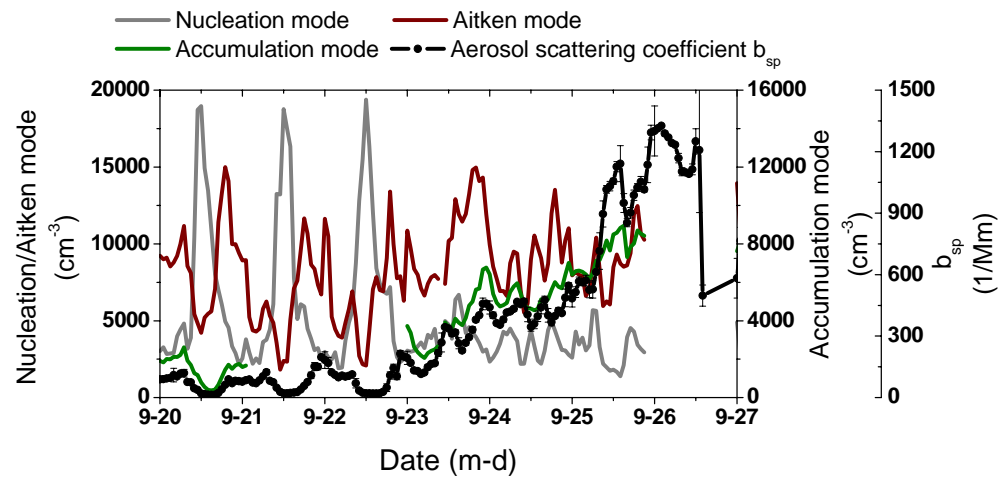

Fig. 10. Temporal variations of the measured aerosol scattering coefficient $b_{\mathrm{sp}}$ and aerosol number concentrations for nucleation mode, Atiken mode, and accumulation mode.

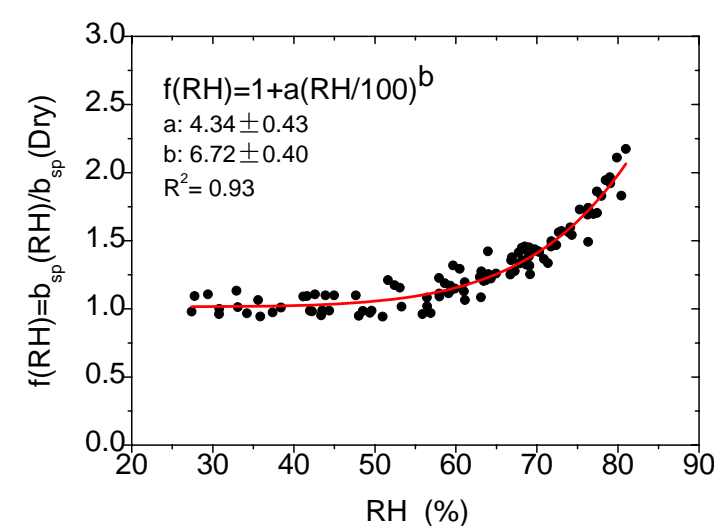

Fig. 11. Hygroscopic growth for aerosol scattering $f(\mathrm{RH})$ as a function of RH with curve fitting. Scattered dots are the measured $f(\mathrm{RH})$ and the line is the empirical fitting curve.

$f(\mathrm{RH})=1+a\left(\mathrm{RH} \times 100^{-1}\right)^{b}$. The curve fitting parameters $a$ and $b$ were 4.34 and 6.72 , respectively, during the measurement period. The $f(\mathrm{RH})$ at $80 \% \mathrm{RH}$ was $1.97 \pm 0.21$ with mean and standard deviation, i.e., under $80 \%$ RH condition, aerosol scattered nearly two times (more) of light relative to that at dry condition. Moreover, the aerosol scattering generally attributed to nearly $80 \%$ of total atmospheric extinction. So, in case of high RH, its extinction effects would be also amplified with the particles hygroscopic growth. Atmospheric extinction coefficient $b_{\text {ext }}$ (dry) under dry condition could be calculated by Eq. (4):

$b_{\text {ext }}($ dry $)=b_{\text {sp }}($ dry $)+b_{\text {ap }}+b_{\text {sg }}+b_{\text {ag }}$.

The visibility under dry condition was then calculated by Eq. (1). The average visibility during 20-27 September in Beijing was $22.3 \mathrm{~km}( \pm 26.3 \mathrm{~km})$ under the dry condition, but its value was $10.5 \mathrm{~km}( \pm 9.2 \mathrm{~km})$ because of the hygroscopic growth of aerosol scattering under ambient RH. Aerosol hygroscopic properties played an important role on visibility degradation, and the haze was an extreme example of this property.
Mass concentrations of $\mathrm{PM}_{2.5}$ could not properly explain the reasons for reduced visibility because of the fact that haze also associated with the aerosol chemical hygroscopic components and its hygroscopic growth factor $f(\mathrm{RH})$ (Malm and Day, 2001; Cheng et al., 2008a,b; Liu et al., 2008). Atmospheric extinction coefficient $b_{\text {ext }}(\mathrm{RH})$ under ambient condition could be expressed by an approximate Eq. (5) (Hand and Malm, 2007; Malm and Hand, 2007):

$$
\begin{aligned}
b_{\text {ext }}(\mathrm{RH}) & =b_{\mathrm{sp}}(\mathrm{RH})+b_{\mathrm{ap}}+b_{\mathrm{sg}}+b_{\mathrm{ag}} \\
& =Q_{\mathrm{sp}} \times \mathrm{PM}_{2.5} \times\left(1+a \times\left(\frac{\mathrm{RH}}{100}\right)^{b}\right) \\
& +Q_{\mathrm{ap}} \times \mathrm{PM}_{2.5}+24,
\end{aligned}
$$

where $Q_{\text {sp }}$ and $Q_{\text {ap }}$ are the mass scattering and absorption efficiency, and the value for $Q_{\mathrm{sp}}, Q_{\mathrm{ap}}$ were $5.3 \mathrm{~m}^{2} \mathrm{~g}^{-1}$, and $0.6 \mathrm{~m}^{2} \mathrm{~g}^{-1}$ according to the statistics value from the ratio of $b_{\text {sp }}$ and $b_{\text {ap }}$ to $\mathrm{PM}_{2.5}$, respectively, which were omitted in this study. The empirical fitting coefficients $a$ and $b$ were 4.34 and 6.72 , respectively. Additionally, the mean value of $14 \mathrm{M} \mathrm{m}^{-1}$ for $b_{\mathrm{ag}}$ during the measurement period was used as the model value for light absorption by gaseous pollutants. Extinction by gas $b_{\mathrm{sg}}$ is assumed to be constant with the value of $10 \mathrm{M} \mathrm{m}^{-1}$; therefore, the sum of the value of $b_{\mathrm{ag}}$ and $b_{\mathrm{sg}}$ was 24 as demonstrated in Eq. (5). The atmospheric visibility in a unit of $\mathrm{km}$ was ultimately converted from this atmospheric extinction coefficient $b_{\text {ext }}(\mathrm{RH})$ by Eq. (1).

The equivalent curve for visibility depending on the mass concentration of $\mathrm{PM}_{2.5}$ and $\mathrm{RH}$ is illustrated in Fig. 12. In general, the atmospheric visibility decreased with the increasing mass concentration of $\mathrm{PM}_{2.5}$ and the visibility would decrease sharply with higher RH. The visibility would be less than $3.0 \mathrm{~km}$ when the mass concentration of $\mathrm{PM}_{2.5}$ was larger than $200 \mathrm{\mu g} \mathrm{m}^{-3}$. For example, the visibility was only $1.7 \mathrm{~km}$ when the mass loading of $\mathrm{PM}_{2.5}$ was $220 \mu \mathrm{g} \mathrm{m}{ }^{-3}$ under $70 \% \mathrm{RH}$ at midnight of 26 September. Under dry condition, the mass concentration of $\mathrm{PM}_{2.5}$ should not exceed $60 \mu \mathrm{g} \mathrm{m}^{-3}$ in order to make visibility no less than $10 \mathrm{~km}$ (see 


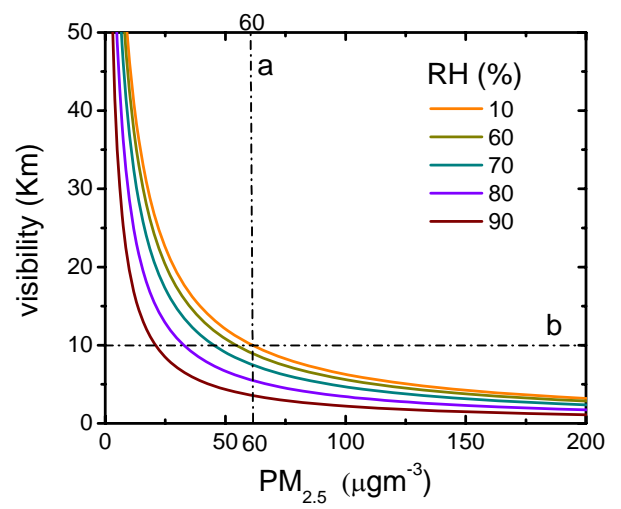

Fig. 12. The equivalent curve for visibility depending on the mass concentration of $\mathrm{PM}_{2.5}$ and relative humidity. Line (b) is the standard for visibility equal to $10 \mathrm{~km}$, and line (a) is the limit for mass concentration of $\mathrm{PM}_{2.5}$ under dry condition $(\mathrm{RH}=10 \%)$.

cross line $\mathrm{a}$ and $\mathrm{b}$ in Fig. 12). Taking the RH into consideration, the mass concentration of $\mathrm{PM}_{2.5}$ should be less than this value $\left(60 \mu \mathrm{g} \mathrm{m}^{-3}\right)$. For example, the mass concentration of $\mathrm{PM}_{2.5}$ should be less than $30 \mu \mathrm{g} \mathrm{m}^{-3}$ when the $\mathrm{RH}$ arriving at $80 \%$.

\section{Conclusions}

In this study, the evolution of haze in Beijing from 2027 September 2011 was investigated in order to clarify the formation mechanism of this regional haze event. Comprehensive measurements of aerosol characteristics and relevant gas pollutants as well as meteorological conditions were conducted at the PKU urban atmospheric environment monitoring station. Meanwhile, aerosol spatial distribution and the height of PBL were retrieved from the signal of MODIS and LIDAR.

Concentrations of $\mathrm{NO}, \mathrm{NO}_{2}, \mathrm{SO}_{2}, \mathrm{O}_{3}, \mathrm{CO}$, and $\mathrm{PM}_{2.5}$ observed during 23-27 September had exceeded the national ambient air quality standards for residents. The mass loading of $\mathrm{PM}_{2.5}$ gradually accumulated and its instantaneous value reached at $220 \mathrm{\mu g} \mathrm{m}^{-3}$ on the midnight of 26 September and daily average was $143 \mu \mathrm{g} \mathrm{m}^{-3}$. The value of daily averaged AOD at Beijing urban area increased from $\sim 0.16$ at $\lambda=500 \mathrm{~nm}$ on 22 September and reached $\sim 3.5$ on 26 September. The value of AOD increased nearly 22 times from clear day to haze day.

The formation of severe haze episodes was a combination of many factors. Firstly, haze formation and evolution depend on both meteorological conditions and emission intensity. Beijing-Tianjin-Tangshan Region was dominated by weak high pressure during the measurement. The high-pressure system resulted in clear sky, subsiding airflow, and relatively stagnant conditions. Ample sunlight and higher temperature provided favorable conditions for photochemical reactions at the beginning. Furthermore, calm wind caused a build-up of pollutants in the Beijing area and air pollutants wandered inside the source region. Meanwhile, the airflow would subside due to the divergence of the air on the surface, which restricted the development of the height of the PBL and limited the vertical mixing of air pollutants. The height of the PBL on 25 September was half of the height of the $\mathrm{PBL}$ on 23 September, the mass concentration of $\mathrm{PM}_{2.5}$ on 25 September $\left(156.5 \pm 35.9 \mu \mathrm{g} \mathrm{m}^{-3}\right)$ was 2.3 times of that $\left(69.7 \pm 25.3 \mu \mathrm{g} \mathrm{m}^{-3}\right)$ on 23 September, and the mass loading of particles in the atmosphere on 25 September was $\sim 2.6$ times of that on 23 September. The inflow of aerosols to Beijing was smaller and the large scale circulation was relatively weak, therefore, the sharp increase of AOD at Beijing during the measurement indicated that this haze episode was also due to the high intensity of local anthropogenic emissions. Secondly, nanoparticle events occurred on 20-22 September, and nanoparticles subsequently grew larger in diameter to the accumulation mode through heterogeneous reactions or coagulation. The increase of the number concentration of aerosols in accumulation mode as well as the increase of their size, resulted in the increase in light scattering, which ultimately induced the occurrence of haze. Lastly, the RH in the beginning of the measurement was $<60 \%$ and increased with maximum of $75 \sim 80 \%$ at the latter phase of haze event. The ambient hydrophilic aerosols absorbed water vapor and scattered more light with the ambient RH increasing, aerosol under $80 \% \mathrm{RH}$ scattered nearly two times of light relative to that at dry condition.

In summary, the key factors that affected the formation and evolution of haze were (1) stable anti-cyclone synoptic conditions at the surface, (2) reduction of the height of PBL, (3) heavy pollution emissions from urban area, (4) number and size evolution of aerosols and (5) hygroscopic growth for aerosol scattering.

Acknowledgements. This work was supported by the National Natural Science Foundation of China (Grant No. 41175018, 41005063, and 20977001) and the Ministry of Science and Technology of China (2013CB955804). The authors thank Chengcai Li and Yafang Cheng for helpful discussions, and we also thank anonymous reviewers for their constructive comments.

Edited by: L. M. Russell

\section{References}

Bell, M. L., Cifuentes, L. A., Davis, D. L., Cushing, E., and Telles, A. G.: Gouveia, N. Environmental health indicators and a case study of air pollution in Latin American cities, Environ. Res., 111, 57-66, 2011.

Bevan, S. L., North, P. R. J., Los, S. O., and Grey, W. M. F.: A global dataset of atmospheric aerosol optical depth and surface reflectance from AATSR, Remote Sens. Environ., 116, 199-210, 2012. 
Chameides, W. L., Yu, H., Liu, S. C., Bergin, M., Zhou, X., Mearns, L., Wang, G., Kiang, C. S., Saylor, R. D., Luo, C., Huang, Y., Steiner, A., and Giorgi, F.: Case study of the effects of atmospheric aerosols and regional haze on agriculture: an opportunity to enhance crop yields in China through emission controls?, P. Natl. Acad. Sci. USA, 96, 13626-13633, 1999.

Chen, L. W. A., Chow, J. C., Doddridge, B. G., Dickerson, R. R., Ryan, W. F., and Mueller, P. K.: Analysis of a summertime PM 2.5 and haze episode in the mid-Atlantic region, J. Air Waste Mange. Assoc., 53, 946-956, 2003.

Cheng, Y. F., Eichler, H., Wiedensohler, A., Heintzenberg, J., Zhang, Y. H., Hu, M., Herrmann, H., Zeng, L. M., Liu, S., Gnauk, T., Brüggenmann, E., and He, L. Y.: Mixing state of elemental carbon and non-light-absorbing aerosol components derived from in situ particle optical properties at Xinken in Pearl River Delta of China, J. Geophys. Res., 111, D20204, doi:10.1029/2005JD006929, 2006.

Cheng, Y. F., Wiedensohler, A., Eichler, H., Heintzenberg, J., Tesche, M., Ansmann, A., Wendisch, M., Su, H., Althausen, D., Herrmann, H., Gnauk, T., Bruggemann, E., Hu, M., and Zhang, Y. H.: Relative humidity dependence of aerosol optical properties and direct radiative forcing in the surface boundary layer at Xinken in Pearl River Delta of China: An observation based numerical study, Atmos. Environ., 42, 6373-6397, 2008a.

Cheng, Y. F., Wiedensohler, A., Eichler, H., Su, H., Gnauk, T., Brüggemann, E., Herrmann, H., Heintzenberg, J., Slanina, J., Tuch, T., Hu, M., and Zhang, Y. H.: Aerosol optical properties and related chemical apportionment at Xinken in Pearl River Delta of China, Atmos. Environ., 42, 6351-6372, 2008b.

Deng, X., Tie, X., Wu, D., Zhou, X., Bi, X., Tan, H., Li, F., and Jiang, C.: Long-term trend of visibility and its characterization in the Pearl River Delta (PRD) region, China, Atmos. Environ., 42, 1424-1435, 2008.

Du, H. H, Kong, L. D., Cheng, T. T., Chen, J. M., Du, J. F., Li, L., Xia, X. A., Leng, C. P., and Huang, G. H.: Insights into summertime haze pollution events over Shanghai based on online water-soluble ionic composition of aerosols, Atmos. Environ., 45, 5131-5137, 2011.

Fu, Q. Y., Zhuang, G. S., Wang, J., Xu, C., Huang, K., Li, J., Hou, B., Lu, T., and Streets, D. G.: Mechanism of formation of the heaviest pollution episode ever recorded in the Yangtze River Delta, China, Atmos. Environ., 42, 2023-2036, 2008.

Hand, J. L. and Malm, W. C.: Review of aerosol mass scattering efficiencies from ground-based measurements since 1990, J. Geophys. Res., 112, D16203, doi:10.1029/2007JD008484, 2007.

Hayden, K. L., Anlauf, K. G., Hoff, R. M., Strapp, J. W., Bottenheim, J. W., Wiebe, H. A., Froude, F. A., and Martin, J. B.: The vertical chemical and meteorological structure of the boundary layer in the Lower Fraser Valley during Pacific 93, Atmos. Environ., 31, 2089-2105, 1997.

He, K., Yang, F., Ma, Y., Zhang, Q., Yao, X., Chan, C. K., Cadle, S., Chan, T., and Mulawa, P.: The characteristics of $\mathrm{PM}_{2.5}$ in Beijing, China, Atmos. Environ., 35, 4959-4970, 2001.

Hegg, D., Larson, T., and Yuen, P.-F.: A theoretical study of the effect of relative humidity on light scattering by tropospheric aerosols, J. Geophys. Res., 98, 18435-18439, 1993.

Hodkinson, R. J.: Calculations of colour and visibility in urban atmospheres polluted by gaseous $\mathrm{NO}_{2}$, Int. J. Air Water Pollut., 10, 137-144, 1966.
Huebert, B. J., Bates, T., Russell, P. B., Shi, G. Y., Kim, Y. J., Kawamura, K., Carmichael, G., and Nakajima, T.: An overview of ACE-Asia: Strategies for quantifying the relationships between Asian aerosols and their climatic impacts, J. Geophys. Res., 108 1-20, 2003.

Kang, H., Zhu, B., Su, J., Wang, H., Zhang, Q., and Wang, F.: Analysis of a long-lasting haze episode in Nanjing, China, Atmos. Res., 120-121, 78-87, doi:10.1016/j.atmosres.2012.08.004, 2013.

Kim, S. W., Yoon, S. C., Won, J. G., and Choi, S. C.: Ground-based remote sensing measurements of aerosol and ozone in an urban area: A case study of mixing height evolution and its effect on ground-level ozone concentrations, Atmos. Environ., 41, 70697081, 2007.

Koschmieder, H.: Theorie der horizontalen Sichtweite, Beitr. Phys. frei. Atmos., 12, 33-53, 1924.

Kulmala, M., Maso, D., Makela, J. M., Pirjola, L., Vakeva, M., Aalto, P., Miikkulainen, P., Hameri, K., and O’Dowd, C. D.: On the formation, growth and composition of nucleation mode particles, Tellus B, 53, 479-490, 2001.

Lee, D. O.: Trends in summer visibility in London and Southern England 1962-1979, Atmos. Environ., 17, 151-159, 1983.

Li, C., Lau, K. H., Mao, J., and Chu, D. A.: Retrieval, validation and application of the 1-km aerosol optical depth from MODIS measurements over Hong Kong, IEEE T. Geosci. Remote, 43, 2650-2658, 2005.

Liu, X. G., Cheng, Y. F., Zhang, Y. H., Jung, J. S., Sugimoto, N., Chang, S.-Y., Kim, Y. J., Fan, S. J., and Zeng, L. M.: Influences of relative humidity and particle chemical composition on aerosol scattering properties during the 2006 PRD campaign, Atmos. Environ., 42, 1525-1536, 2008.

Liu, X. G., Zhang, Y. H., Jung, J. S., Gu, J. W., Li, Y. P., Guo, S., Chang, S.-Y., Yue, D., Lin, P., Kim, Y. J., Hu, M., Zeng, L. M., and Zhu, T.: Research on Aerosol Hygroscopic Properties by Measurement and Model during the 2006 CARE Beijing Campaign, J. Geophys. Res., 114, D00G16, doi:10.1029/2008JD010805, 2009.

Liu, X. G., Zhang, Y. H., Wen, M. T., Wang, J. L., Jung, J. S., Chang, S.-Y., Hu, M., Zeng, L. M., and Kim, Y. J.: A Closure Study of Aerosol Hygroscopic Growth Factor during the 2006 PRD Campaign, Adv. Atmos. Sci., 27, 947-956, doi:10.1007/s00376-0099150-z, 2010.

Malm, W. C. and Day, D. E.: Estimates of aerosol species scattering characteristics as a function of relative humidity, Atmos. Environ., 35, 2845-02860, 2001.

Malm, W. C. and Hand, J. L.: An examination of the physical and optical properties of aerosols collected in the IMPROVE program, Atmos. Environ., 41, 3407-3427, 2007.

McNulty, R. P.: The effect of air pollutants on visibility in fog and haze at New York city, Atmos. Environ., 2, 625-628, 1968.

Melfi, S. H., Spinhirne, J. D., Chou, S. H., and Palm, S. P.: Lidar observation of vertically organized convection in the planetary boundary layer over the ocean, J. Appl. Meteorol. Clim., 24, 806-821, 1985.

Mukherjee, P. and Viswanathan S.: Contributions to CO concentrations from biomass burning and traffic during haze episodes in Singapore, Atmos. Environ., 35, 715-725, 2001.

Petzold, A. and Schonlinner, M.:, Multi-angle absorption photometry - a new method for the measurement of aerosol light absorp- 
tion and atmospheric black carbon, J. Aerosol Sci., 35, 421-441, 2004.

Quinn, P. K. and Bates, T.: North American, Asian, and Indian haze: Similar regional impacts on climate?, Geophys. Res. Lett., 30, 1555, doi:10.1029/2003GL016934, 2003.

Quinn, P. K., Coffman, D. J., Bates, T. S., Miller, T. L., Johnson, J. E., Welton, E. J., Neususs, C., Miller, M., and Sheridan, P. J.: Aerosol optical properties during INDOEX 1999: Means, variability, and controlling factors. J. Geophys. Res., 107, 8020, doi:10.1029/2000JD000037, 2002.

Russell, L. M., Mensah, A. A., Fischer, E. V., Sive, B. C., Varner, R. K., Keene, W. C., Stutz, J., and Pszenny, A. A. P.: Nanoparticle growth following photochemical $\alpha$ - and $\beta$-pinene oxidation at Appledore Island during International Consortium for Research on Transport and Transformation/Chemistry of Halogens at the Isles of Shoals 2004, J. Geophys. Res., 112, D10S21, doi:10.1029/2006JD007736, 2007.

Schichtel, B. A., Husar, R. B., Falke, S. R., and Wilson, W. E.: Haze trends over the United States, 1980-1995, Atmos. Environ., 35, 5205-5210, 2001.

Seinfeld, J. H. and Pandis, S. N.: Atmospheric Chemistry and Physics: from Air Pollution to Climate Change, 2nd Edn., John Wiley \& Sons, Inc., New York, USA, 2006.

Strawbridge, K. B. and Snyder, B. J.: Planetary boundary layer height determination during Pacific 2001 using the advantage of a scanning lidar instrument, Atmos. Environ., 38, 5861-5871, 2004.

Sugimoto, N., Nishizawa, T., Liu, X. G., Matsui, I., Shimizu, A., Zhang, Y. H., Kim, Y. J., Li, R. H., and Liu, J.: Continuous observations of aerosol profiles with a two-wavelength Mie-scattering lidar in Guangzhou in PRD2006, J. Appl. Meteorol. Clim., 48, 1822-1830, 2009.

Sun, Y. L., Zhuang, G. S., Wang, Y., Han, L. H., Guo, J. H., Dan, M., Zhang, W. J., Wang, Z. F., and Hao, Z. P.: The air-borne particulate pollution in Beijing-Concentration, composition, distribution and sources, Atmos. Environ., 38, 5991-6004, 2004.
Sun, Y. L., Zhuang, G. S., Tang, A. H., Wang, Y., and An, Z. S.: Chemical characteristics of $\mathrm{PM}_{2.5}$ and $\mathrm{PM}_{10}$ in haze-fog Episodes in Beijing, Environ. Sci. Technol., 40, 3148-3155, 2006.

Tang, I. N.: Chemical and size effects of hygroscopic aerosols on light scattering coefficients, J. Geophys. Res., 101, 1924519250,1996

Tie, X. X., Wu, D., and Brasseur, G.: Lung cancer mortality and exposure to atmospheric aerosol particles in Guangzhou, China, Atmos. Environ., 43, 2375-2377, 2009.

Wang, Y., Zhuang, G. S., Sun, Y. L., and An, Z. S.: The variation of characteristics and formation mechanisms of aerosols in dust, haze, and clear days in Beijing, Atmos. Environ., 40, 6579-6591, 2006.

Wu, D., Tie, X., Li, C., Ying, Z., Lau, A. K.-H., Huang, J., Deng, X., and Bi, X.: An extremely low visibility event over the Guangzhou region: a case study, Atmos. Environ., 39, 6568-6577, 2005.

Wu, D., Bi, X., Deng, X., Li, F., Tan, H., Liao, G., and Huang, J.: Effects of atmospheric haze on the deterioration of visibility over the Pearl River Delta, Acta Meteorol. Sin., 64, 510-517, 2006.

Xiao, F., Brajer, V., and Mead, R. W.: Blowing in the wind: the impact of China's Pearl River Delta on Hong Kong's air quality, Sci. Total Environ., 367, 96-111, 2006.

Yadav, A. K., Kumar, K., Kasim, A., Singh, M. P., Parida, S. K., and Sharan, M.: Visibility and incidence of respiratory diseases during the 1998 haze episode in Brunei Darussalam, Pure Appl Geophys., 160, 265-277, 2003.

Yang, D. P.: Crisis and turning of China's environment, Social Sciences Academic Press, 156-160, 2008.

Zhang, Y. H., Hu, M., Zhong, L. J., Wiedensohler, A., Liu, S. C., Andreae, M. O., Wang, W., and Fan, S. J.: Regional integrated experiments on air quality over Pearl River Delta 2004 (PRIDEPRD2004): Overview, Atmos. Environ., 42, 6157-6173, 2008. 